\title{
Productive Verbal Interactions in Classrooms With Children From Different Socioeconomic Backgrounds: An Empirical Study in Chilean Schools
}

\section{Interacciones Verbales Productivas en Aulas con Estudiantes de Distintos Contextos Socioeconómicos: Un Estudio Empírico en Colegios Chilenos}

\author{
Javiera Muñoz-Hurtado \\ Universidad de Tarapacá
}

\begin{abstract}
The purpose of this study was to explore the characteristics of classroom talk in 2 Chilean schools located in Santiago. Both schools, which were purposively selected, have a shared interest in dialogue, but serve students from different socioeconomic status [SES] backgrounds. Observations of naturally occurring verbal interactions in 3 consecutive science lessons were conducted in 4 th grade classrooms. Interactions between the teacher and the whole class were examined adopting a sociocultural discourse analysis approach, using both quantitative and qualitative data. Results show that verbal interactions with students from a lower SES background tend to be more concrete and adultdependent. Talk in this classroom was characterised by a predominance of closed questions; however, this is not a sign of less productive interaction, but evidence of a different way of using language in academic interactions taking place in more vulnerable contexts. It is suggested that teachers and researchers need to acknowledge these linguistic characteristics of students from lower SES backgrounds in order to promote meaningful classroom talk.
\end{abstract}

Keywords: classroom verbal interaction, productive interactions, socioeconomic background, observational study

\begin{abstract}
El propósito de este estudio fue explorar las características de la interacción verbal en aula de 2 colegios chilenos de Santiago, seleccionados intencionalmente, que comparten el interés por el diálogo, pero que atienden a estudiantes de diferente nivel socioeconómico [NSE]. Se realizaron observaciones naturales de interacciones verbales en 3 clases consecutivas de $4^{\circ}$ básico durante la asignatura de Ciencias. Las interacciones entre profesor y la clase completa se examinaron desde el enfoque del análisis sociocultural del discurso, considerando tanto datos cuantitativos como cualitativos. Los resultados de este estudio muestran que las interacciones verbales con estudiantes de bajo NSE tienden a ser más concretas y dependientes del adulto. El habla en esta aula se caracterizó por una mayor predominancia de preguntas cerradas; sin embargo, esto no es sinónimo de interacciones menos productivas, sino que evidencia un uso diferente del lenguaje en interacciones académicas en contextos más vulnerables. Se sugiere la necesidad de que profesores e investigadores reconozcan estas características lingüísticas de estudiantes de menor NSE para promover diálogos significativos en el aula.
\end{abstract}

Palabras clave: interacción verbal en el aula, interacciones productivas, contexto socioeconómico, estudio observacional

In the last four decades there has been great interest in understanding what are the characteristics of classroom talk (Howe \& Abedin, 2013; Mercer \& Dawes, 2014). This interest is understandable as it is widely recognised that the quality of classroom talk has implications for how children learn (Edwards \& Mercer, 1987; Littleton \& Howe, 2010; Wells, 1999). Nevertheless, as remarked by Cazden (2001), learning is not the only purpose of language in school, it also fulfils the function of controlling social relations and allowing the expression of identities. Recognising that socioeconomic status [SES] is a variable that impact quality of education, it is relevant to study how classroom talk allows learning and the development of social and individual identities in schools serving communities of different SES. Until now, there has been very little research on this topic. The only study that has addressed this issue was conducted by Harris and Williams (2012), who identified that the quality of classroom verbal interaction in schools of lower SES is similar to the classroom verbal interaction of younger children from schools of higher SES.

Javiera Elisa Muñoz-Hurtado, Escuela de Medicina, Facultad de Ciencias de la Salud, Universidad de Tarapacá, Arica, Chile.

Correspondence concerning this article should be addressed to Javiera Elisa Muñoz-Hurtado, Escuela de Medicina, Facultad de Ciencias de la Salud, Universidad de Tarapacá, Av. 18 de Septiembre 2222, Código Postal 1010069, Arica, Chile. E-mail: javieraelisa.mh@gmail.com 
MUÑOZ-HURTADO

\section{Classroom Talk in Whole-Class Interaction}

Talk in the classroom has special features that make it different from conversations in other settings. Years ago, Sinclair and Coulthard (1975) identified a basic communicative pattern in classroom interactions, the Teacher Initiation, Student Response and Teacher Follow-up (IRF). Researches around the world have described that classroom interaction is typically characterised by teachers' closed factual questions, students' short answers and undemanding feedback from teachers (Abd-Kadir \& Hardman, 2007; Alexander, 2000; Molinari, Mameli, \& Gnisci, 2013; Myhill, 2006). As have been shown by Preiss (2009) and Preiss, Larrain, and Valenzuela (2011), Chilean classrooms are not the exception. With a large set of data, these authors evidenced that students in Chile are not being cognitively challenged by their teachers, since classroom communication is mainly focused on information transmission and skills training, rather than on the promotion of reasoning.

Along with the IRF pattern, Mortimer and Scott (2003) proposed another relevant distinction in their classroom communicative approach. They defined four types of classroom discourse based on two dimensions: authoritative/dialogic and interactive/non-interactive. While authoritative discourse focuses only on one perspective, dialogic discourse is open to different point of views. Dialogic discourse may also be considered non-interactive if the different ideas are just presented, without exploring their connections or contrasts. In an interactive/authoritative discourse, students are participating in the dialogue, but rather than expressing their own ideas, they are moving in the verbal interactions towards an understanding of content that the teacher wants to consolidate. Scott, Mortimer, and Aguiar (2006) highlight that in classroom talk both the dialogic and the authoritative discourses are pertinent in their different interactive and non-interactive forms, depending on the purpose of the activity.

\section{Productive Interactions}

Lefstein (2010) makes a significant distinction regarding productive interactions, which need to be understood in relation to the different dimensions of classroom dialogue, namely, the meta-communicative, interpersonal, cognitive, and aesthetic dimensions. Even though the four dimensions are relevant, this study focuses only on the interpersonal and cognitive dimensions. Considering these two dimensions, this study understands productive interactions in terms of paying attention to the social relationships and students' contributions in the classroom (interpersonal dimension), and in terms of how language is used to associate knowledge with everyday experiences, connect ideas and for calling into question students' ideas by introducing different point of views (cognitive dimensions).

Regarding the interpersonal dimension, it has been evidenced that students have limited opportunities to participate in the classroom. Studies in England have shown that students' contributions are very short, between three and four words (Hardman, Smith, \& Wall, 2003; Myhill, 2006). In Chile, the same kind of brief participation has been observed, with the majority of students' responses being only between one and two words (Radovic \& Preiss, 2010). Regarding the cognitive dimension, there are different forms in which the teacher can challenge their students. Teachers can help their students to develop their understanding of a topic through direct or cued elicitation (Edwards \& Mercer, 1987). These interactions may be useful, but it is acknowledged that effective teachers also use questions and feedback to ask their students to explain and analyse their ways of thinking (Larraín, Howe, \& Cerda, 2014). In this line, Jones and Tanner (2002) found that effective whole-class interactions took place when students were guided by their teachers in a type of interaction that focused on a problematic feature promoting the students' reflection. This is different from other less demanding scaffolding interactions that funnel students by means of pre-planned strategies to give the right answer known by the teacher (Wood, 1994).

\section{Classroom Talk and Socioeconomic Background}

The mixed-method study conducted by Harris and Williams (2012) constitutes the only investigation that compares differences in classroom talk between schools with children from different socioeconomic backgrounds. Using data collected in single observations in 102 classrooms (reception, year 2 and year 4) in 20 British schools and through regression analysis, they found differences in the quality of classroom verbal interaction depending on the school SES. It is important to notice that in this work quality was assessed regarding the proportion of open questions, waiting time and students' correct answers. In a similar line, 
other studies have investigated the relationship between social disadvantage, language development, and school performance, founding differences in relation to vocabulary, comprehension, language production, complexity of speech and sentence length (Spencer, Clegg, \& Stackhouse, 2012).

Beyond classroom talk research, the work of Bernstein (1970) is an important attempt to explain how children from diverse SES interact through language differently due to the verbal relations they experience at home. He explains that children from higher social class are normally spoken to in an elaborated code, in which speech is more abstract and less context-bounded. By contrast, children from the lower class would be exposed to a restricted code, which is more particularistic and severely context-bounded. Another relevant concept developed by Bernstein (2000) is the concept of framing, which refers to how communication is controlled. In pedagogical interactions, when framing is strong, the teacher controls the interaction, whereas when framing is weaker, the students are in greater control of the communication. The characteristics of weaker framing, as well as elaborated codes, has been associated in research with socially dominant groups (Cheshire, 2005; Hasan, 2002). Cazden (2001) also refers to an experiment, where she found that 11-year-old boys from lower and middle class performed similarly in a descriptive task, however, lower-class children needed more adult prompts to complete it satisfactorily.

\section{Overview of the Research}

The main aim of this study was to identify the characteristics of the classroom talk of schools that serve communities of different SES. In Chile, the issue of social inequality is acknowledged as the main determinant of the quality of school education in terms of academic outcomes (Bellei, 2013; Mizala \& Torche, 2012; Organisation for Economic Co-operation and Development, 2010). In this scenario, the variations in specific forms of classroom talk in terms of socioeconomic background would affect classrooms as a whole, and not just some children from diverse social origins, as would be the case in a more heterogeneous school system.

This study aimed to explore this gap in the literature on classroom talk research trying to reach a contextualised understanding of the verbal interaction in two classrooms of two socioeconomically opposite contexts. Two research questions were defined to guide this study:

1. Does the pattern of classroom talk vary in classrooms where the children are from communities of very different socioeconomic status? For the pattern of classroom talk the different types of questions and follow-ups made by the teacher are considered, as well as the frequency and length of students' responses.

2. If so, does this variation imply different types of productive interactions in the two specific contexts? The types of productive interactions are understood, as defined by Mortimer and Scott (2003), based on two dimensions: authoritative/dialogic and interactive/non-interactive. The characteristics of the interpersonal and cognitive dimensions highlighted in the literature are also added to analyse the productive interactions.

Productive interactions in this investigation were analysed considering the interpersonal and cognitive dimensions. The interpersonal dimension was examined in terms of how open, responsive, and flexible the teachers were to students' contributions. The cognitive dimension was studied in terms of the cognitive demand the teacher placed to their students and the level of attunement in the contextualised dialogue, bearing in mind the students' specific characteristics.

\section{Method}

\section{Participants}

A small-sample observational comparative study was conducted in two classrooms in schools serving communities from different socioeconomic backgrounds in Santiago, Chile. The two schools selected are emblematic schools which share a concern about developing dialogue in education, as stated in their educative institutional projects, but varied greatly in the SES of their students. Both schools make explicit their concern to use dialogues as tools for learning in their educational projects. While the school of low SES is based on popular education pedagogy, where dialogues are central for learning, the high SES school declares in its central educational proposals the active participation of students in their learning through dialogues and interaction. 
In this sense, a purposive sample (Robson, 2011) was selected, as participants were chosen on the basis of their specific characteristics related to the goal of the research, with the expectation that they would evidence interesting features about the phenomenon under study.

The differences and common features of the participants in the sample and their school context can be observed in Table 1.

Table 1

Characteristics of the Sample

\begin{tabular}{|c|c|c|c|c|}
\hline School & SES & Classroom & Teacher & Pupils \\
\hline \multirow{3}{*}{ High SES } & parents' education: 16 years & $4^{\text {th }}$ grade & female & $\begin{array}{l}27 \text { students } \\
\quad(8 \text { girls })\end{array}$ \\
\hline & $\begin{array}{l}£ 1,300 \text { monthly family } \\
\text { income }\end{array}$ & $\begin{array}{c}3 \text { consecutive science } \\
\text { lessons }\end{array}$ & $\begin{array}{l}15 \text { years teaching } \\
\text { experience in the } \\
\text { school }\end{array}$ & $9-10$ years old \\
\hline & $\begin{array}{l}6 \% \text { of students in social } \\
\text { vulnerability condition }\end{array}$ & & & \\
\hline \multirow{3}{*}{ Low SES } & parents' education: 8 years & $4^{\text {th }}$ grade & female & $\begin{array}{l}20 \text { students } \\
\quad(9 \text { girls })\end{array}$ \\
\hline & $\begin{array}{l}£ 200 \text { monthly family } \\
\text { income }\end{array}$ & $\begin{array}{c}3 \text { consecutive science } \\
\text { lessons }\end{array}$ & $\begin{array}{l}18 \text { years teaching } \\
\text { experience in the } \\
\text { school }\end{array}$ & $9-13$ years old \\
\hline & $\begin{array}{l}81 \% \text { of students in social } \\
\text { vulnerability condition }\end{array}$ & & & \\
\hline
\end{tabular}

Note. Information of SES of the schools' families was extracted from the government website www.simce.cl

\section{Procedure}

Before starting data collection, it was ensured that all participants understood the purpose of the study and the future use of its results. Teachers and head-teachers were asked to sign an informed consent, in which they were informed about the investigation and their right to withdraw at any time without giving any reason for it. Parents were notified by a letter including a passive parental consent (Robson, 2011). Pupils were also verbally informed about their participation and their right to not take part, if desired.

The best way to study how teachers and students verbally interact in the classroom is through direct observation. As snapshot observations are unlikely to produce valid representations of the reality of the classroom interaction (Mercer, 2010), in each classroom three complete consecutive science lessons were observed and videotaped. All six lessons were held in the morning and were made during the month of April of 2015. In total, three hours and 39 minutes were video-recorded in the low SES school and three hours and 36 minutes in the high SES school. Only whole-class dialogues were selected for transcription, comprising one hour and 21 minutes and one hour and 14 minutes, respectively. All whole-class dialogues were considered in the quantitative analysis.

\section{Data Analysis}

Sociocultural discourse analysis was chosen for this investigation, as it emphasises the contextualised nature of classroom talk, focusing on how language is used to develop a collective understanding in classroom interactions (Mercer, 2004, 2010). A significant feature of this type of analysis is that even though data can be quantified, the relationship with the actual words is not missed. Typical forms of teachers' questions and feedbacks were coded and compared regarding their frequency in each classroom to later analyse them qualitatively. Frequency and length (word count) of students' responses were also quantified. The reliability of the study was ensured by the detailed description of the codification procedure and the triangulation with qualitative data, as explained below. 
Coding scheme. The coding scheme in this study involved only categories emerging from the data analysis to avoid the predefinition of decontextualised categories (Mercer, 2010). A careful and repeated revision of the classroom talk transcription allowed the identification of relevant elements of the particular data. A subsequent revision of the classroom talk literature was helpful in naming the categories within the language research field. Specifically, the studies that were used to construct the categories identified in the data were that of Mercer, (1995), Molinari et al. (2013), Nassaji and Wells (2000), and Preiss (2009). The different categories with their definitions and examples from the data can be seen in Table 2 .

Table 2

Coding Scheme

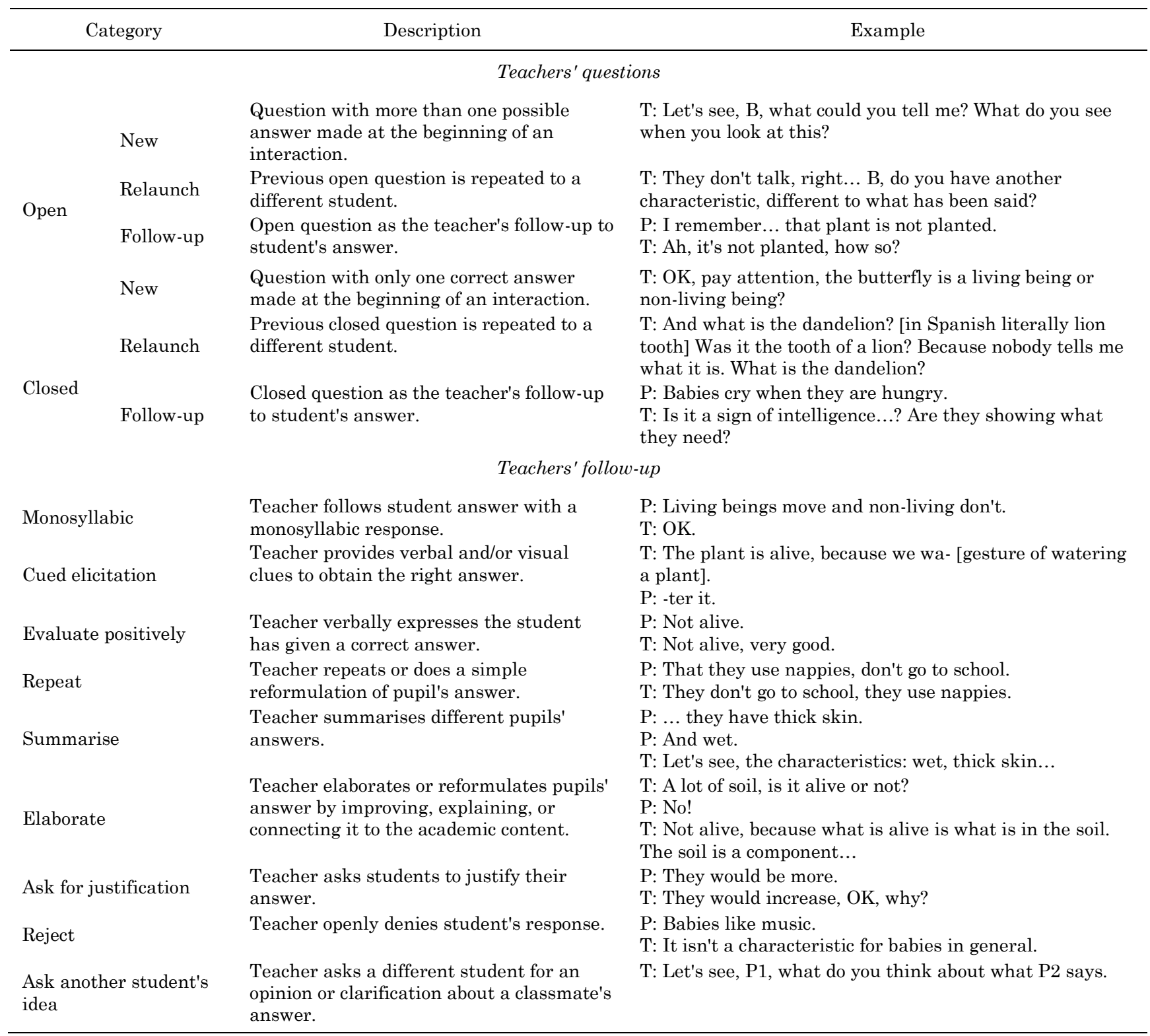

Note. $\mathrm{P}=$ pupil; $\mathrm{T}=$ teacher.

Qualitative analysis. In the frame of sociocultural discourse analysis, productive interactions cannot be defined only by the frequency of occurrence of certain categories (Mercer, 2004); so an extensive revision of the actual classroom talk was undertaken. By reviewing the videos and transcriptions several times, seven extended productive interactions in each classroom were selected as representative of the classroom 
communication in each setting. The criteria for this selection were based on common features, reported in the quantitative analysis, and also in relation to what was defined as productive interactions in the literature review, considering both the cognitive and the interpersonal dimension.

Due to limited space, only one extract from each classroom is shown in this article. These were selected as they provide a clear illustration of the attunement between the teacher and her students in their verbal interaction, in which the subtleties in the use of language can be analysed to create a common understanding of the classroom talk.

\section{Results}

The results of the analysis are presented following the research questions as introduced in the overview section. For the first question, the quantification of the data provided useful information, allowing the numerical comparison of both settings. However, the second question required a more careful analysis of the actual talk, which could only be accomplished by the close observation of classroom talk extracts. Therefore, firstly, the frequencies of the different categories elaborated in the coding scheme are described. And, finally, the classroom talk extracts are analysed concerning each setting.

\section{Quantitative Data}

To visualise the pattern of verbal interaction in both classrooms, the different types of questions and follow-ups made by the teacher, as well as the frequency and length of students' responses were quantified. This information is displayed in Table 3, in which the variation between the schools can be observed.

Table 3

Descriptive Statistics of Classroom Talk

\begin{tabular}{|c|c|c|c|c|c|c|}
\hline \multirow{2}{*}{ Teacher' question and follow-up } & \multicolumn{3}{|c|}{ Low SES school } & \multicolumn{3}{|c|}{ High SES school } \\
\hline & $N$ & $\%$ & Length* & $N$ & $\%$ & Length* \\
\hline \multicolumn{7}{|c|}{ Teacher's questions } \\
\hline Total open questions & 49 & 26 & 14 & 75 & 60 & 10 \\
\hline Open question (new) & 32 & 17 & 16 & 17 & 14 & 17 \\
\hline Relaunch open question & 8 & 4 & 6 & 22 & 18 & 4 \\
\hline Follow-up open question & 9 & 5 & 12 & 36 & 29 & 10 \\
\hline Total closed questions & 137 & 74 & 10 & 50 & 40 & 13 \\
\hline Closed question (new) & 43 & 23 & 15 & 8 & 6 & 20 \\
\hline Relaunch closed question & 2 & 1 & 11 & 2 & 2 & 6 \\
\hline Follow-up closed question & 92 & 49 & 8 & 40 & 32 & 11 \\
\hline Total questions & 186 & 100 & 11 & 125 & 100 & 11 \\
\hline \multicolumn{7}{|c|}{ Teacher's follow-up } \\
\hline Monosyllabic & 6 & 4 & 1 & 4 & 4 & 1 \\
\hline Cued elicitation & 12 & 8 & 9 & 0 & 0 & 0 \\
\hline Evaluate positively & 19 & 13 & 6 & 8 & 7 & 7 \\
\hline Repeat & 61 & 42 & 3 & 45 & 39 & 7 \\
\hline Summarise & 7 & 5 & 23 & 7 & 6 & 56 \\
\hline Elaborate & 18 & 12 & 25 & 14 & 12 & 41 \\
\hline Ask for justification & 14 & 10 & 6 & 14 & 12 & 12 \\
\hline Reject & 8 & 6 & 6 & 12 & 10 & 12 \\
\hline Ask other students' ideas & 0 & 0 & 0 & 11 & 10 & 9 \\
\hline Total follow-ups & 145 & 100 & 8 & 115 & 100 & 15 \\
\hline \multicolumn{7}{|c|}{ Total utterances } \\
\hline Teacher's utterances & 331 & 49 & 10 & 240 & 53 & 13 \\
\hline Students' utterances & 346 & 51 & 4 & 213 & 47 & 11 \\
\hline Total utterances & 677 & 100 & 7 & 453 & 100 & 12 \\
\hline
\end{tabular}


The first difference that comes to light is the variation between open and closed questions among schools $\left(X^{2}=35,32 ; p<.001\right)$. As it is illustrated in Figure 1, while in the classroom in the low SES school there was a clear prevalence of closed questions (74\%), in the high SES school open questions were preponderant (60\%). In the first case, closed questions were mainly follow-up closed questions (49\%), which indicated the development of a topic in the classroom talk through a funnelling conducted by the teacher towards predetermined answers. In the other school, open questions were in the same way mainly follow-up open questions (29\%). Also, the relaunch of open questions (18\%) appeared as a significant feature of that classroom. These two factors were associated with the exposition of a greater variety of answers that were not predefined by the teacher. However, there was also a great proportion of follow-up closed questions (32\%) in this classroom, evidencing that in the high SES classroom the teacher combined both forms of questions, giving space for students' ideas, but also conducting the classroom talk towards specific and predefined content.

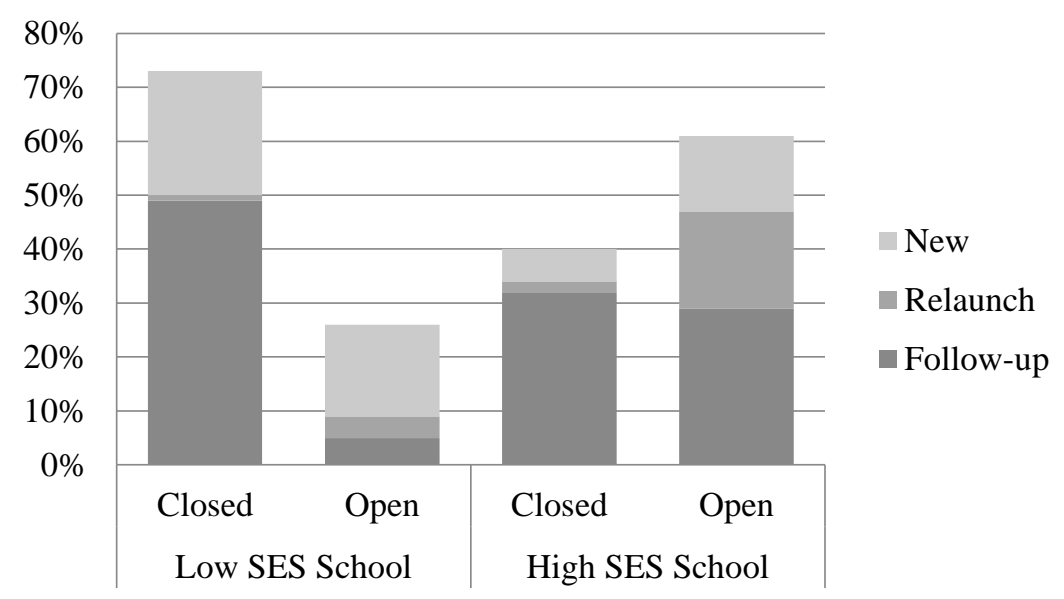

Figure 1. Proportion of different types of teacher's questions per classroom.

In relation to teacher's follow-ups, there is a significant difference among schools in terms of the average utterance's length $(t=-4.09 ; p<.001)$. As it can be seen in Table 3, while in the low SES school their length was eight words per teacher's follow-up, in the more affluent school, utterance's length was of 15 words on average. Also, in Figure 1 it can be seen that many of them took the form of open or closed questions. The different types of follow-up with their respective proportions are presented in Figure 2. Apart from the followup questions, which were the main types of follow-up, it can be seen in the data that teachers from both schools repeated their students' answers to a great extent (42\% in the low SES school and 39\% in the high SES school).

Teachers in this study also elaborated students' answers (12\% in both schools) and asked their students to justify their responses in similar proportions (10\% in low SES school and $12 \%$ in high SES school). However, apart from these similarities, there were certain types of interaction that only occurred in each classroom. In the low SES school, 8\% of the follow-ups consisted of the teacher providing visual or verbal clues to elicit the right answer. It is interesting that this interaction (cued elicitation) did not take place in the other school. Rather a different type of follow-up appeared as exclusive to the high SES school, which consisted of the teacher asking a pupil to elaborate or give his/her opinion about a classmate's response, which occurred in $10 \%$ of the follow-ups in this classroom and not even once in the other setting.

Regarding students' responses, the results indicate that there is a significant difference in the length of their utterances in relation to the socioeconomic background $(t=-7.88 ; p<.001)$. While the average length in the low SES school was of four per utterance, in the more affluent context, students' sentences were of 11 words on average. 


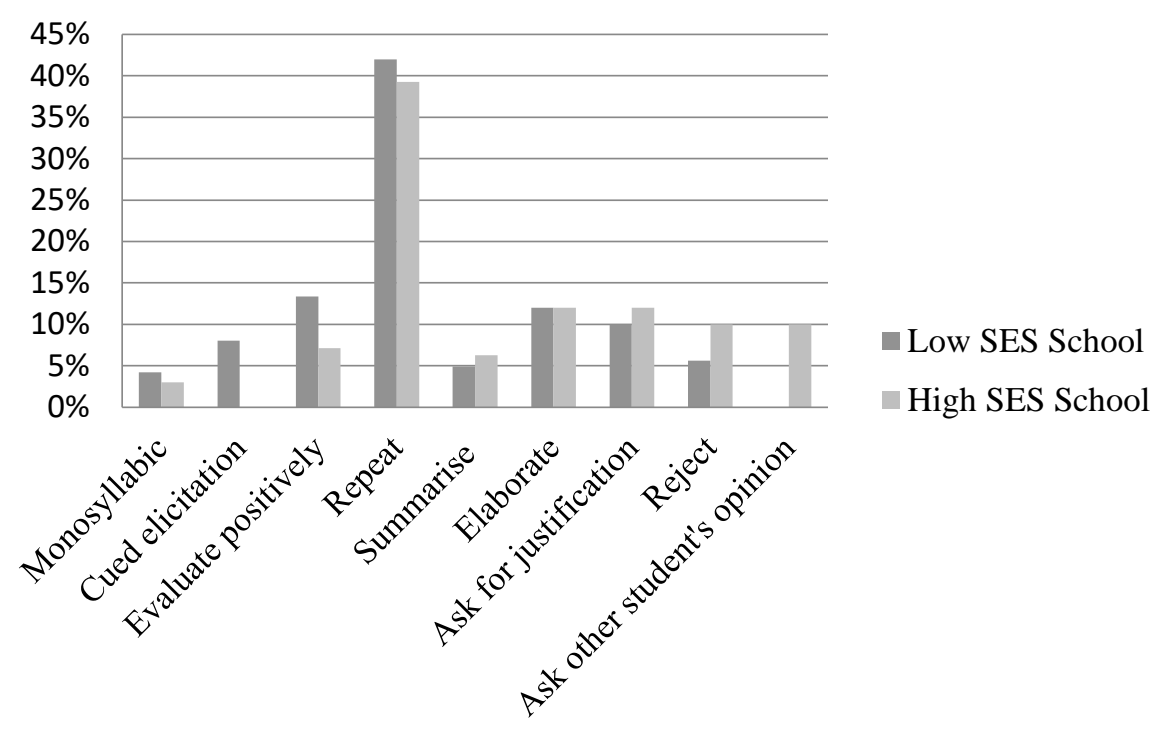

Figure 2. Proportion of different teacher's follow-up.

By quantifying the different elements of classroom talk, the relevant variations between each school context were evidenced. Even though it is difficult for such a small study to assert that these variations were completely attributable to socioeconomic differences, it is relevant here to analyse how these particular features unfolded in the contextualised classroom talk and how they, in their social context, implied the construction of a common understanding. To address this issue, which is in line with the second question of the present study, a careful examination of the classroom talk is undertaken in the next section.

\section{Qualitative Data}

In this section one classroom talk extract from each setting is presented in which the teacher-students dialogue developed productively, that is, where the participants of the conversation were attuned, and there was a clear learning trajectory achieved through the communication. Both extracts dealt with the same topic (about living and non-living beings), which allowed a comparison of how the topic was treated and how dialogue unfolded regarding the same theme in the two different contexts.

Living and non-living, the born and the eaten. Extract from the low SES school. This extract is part of the first lesson, in which the class was starting the unit "Ecosystems in nature". The teacher started this unit by commenting that it was a difficult topic, with difficult words, such as ecosystem. One of the first activities was to define the characteristics of living and non-living beings that interact in an ecosystem. The teacher put the name of different living and non-living beings on the whiteboard and students were requested to say if these beings were alive or not. Firstly, they started by identifying animals, which was an easy task for the children. In this extract (Table 4), they were looking at a different type of living being, a fruit, and the pupils struggled to define whether it was alive or not.

Commentary. This extract represents an authoritative/interactive discourse, as the teacher led the students to a final idea that she wanted her students to grasp. To do so, this teacher used mainly closed questions funnelling student responses, but also requested students to justify their answers. Students responded to the teacher's questions with simple and short answers of four words on average; in fact, only one answer had an extent of more than 10 words (turn 25). Regarding, the interpersonal dimension, it can be seen that pupils actively participated. Six different students took part in this dialogue and seven choral responses were given. Some children gave correct responses, which were taken up by the teacher (turn 15 and 19), but others evidenced more difficulties in accomplishing the task. It is interesting that children called upon direct experience of the object to develop their justification and understanding (turns 3 and 22). The teacher recognised the student's difficulty and simplified the task by referring to something similar but easier to understand (turn 23). In this sense, she provided a cognitive scaffold for her students, who were finally able to achieve the general consensus that the strawberry is alive. In this sequence, the use of visual and 
verbal clues was also evident to help students to accomplish the task (turns 15 and 26), making evident a basic characteristic of living beings: that they grow. Through the verbal interaction, the teacher of this classroom was able to lead a relevant dialogue towards the understanding of basic academic content. The teacher, in this case, seemed to be aware of the needs and difficulties of her students and could direct the classroom talk to take care of those problems. In general, a high level of attunement on the part of the teacher in relation to her students can be seen, as she showed flexibility and the skills to guide a productive interaction that was highly adult dependent.

Table 4

\section{Extract From the Low SES School}

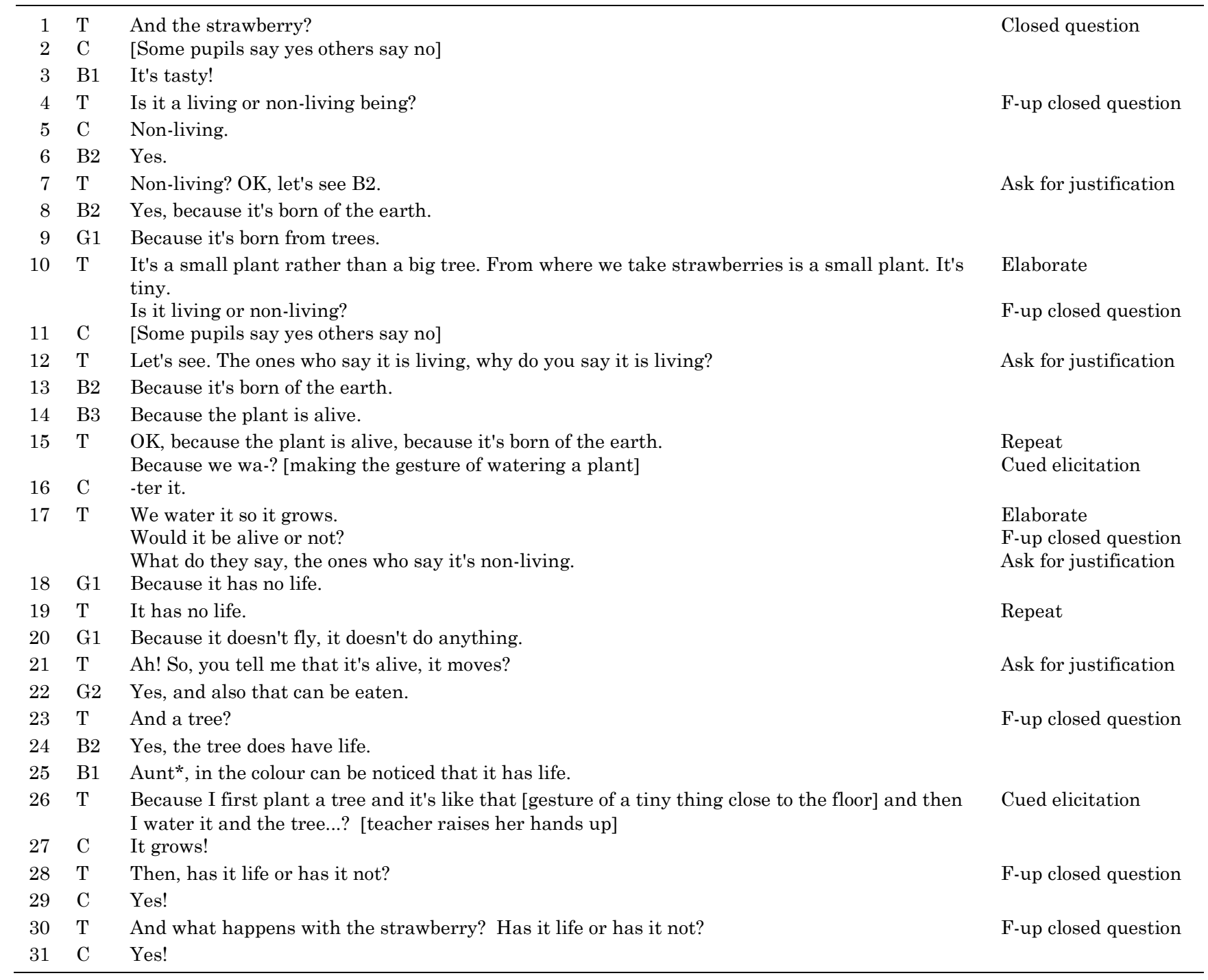

Note. T is the teacher; $\mathrm{B}$ is a boy and $\mathrm{G}$ is a girl; $\mathrm{C}$ is a chorus.

* In Chile it is common to call the teacher aunt or uncle.

Living and non-living, the changing and the inert. Extract from the high SES school. This extract from the high SES school also formed part of the first lesson. Before this dialogue, the teacher had presented the objectives of the new unit that they were starting: "Life cycles". To connect the new topic with students' previous knowledge, she had asked students to remember a unit they had studied two years ago about plants. In this episode, the teacher showed two objects to her students: a cactus and a rock. She asked them to define the characteristics of and differences between living and non-living beings (Table 5). 
Table 5

Extract From the High SES School

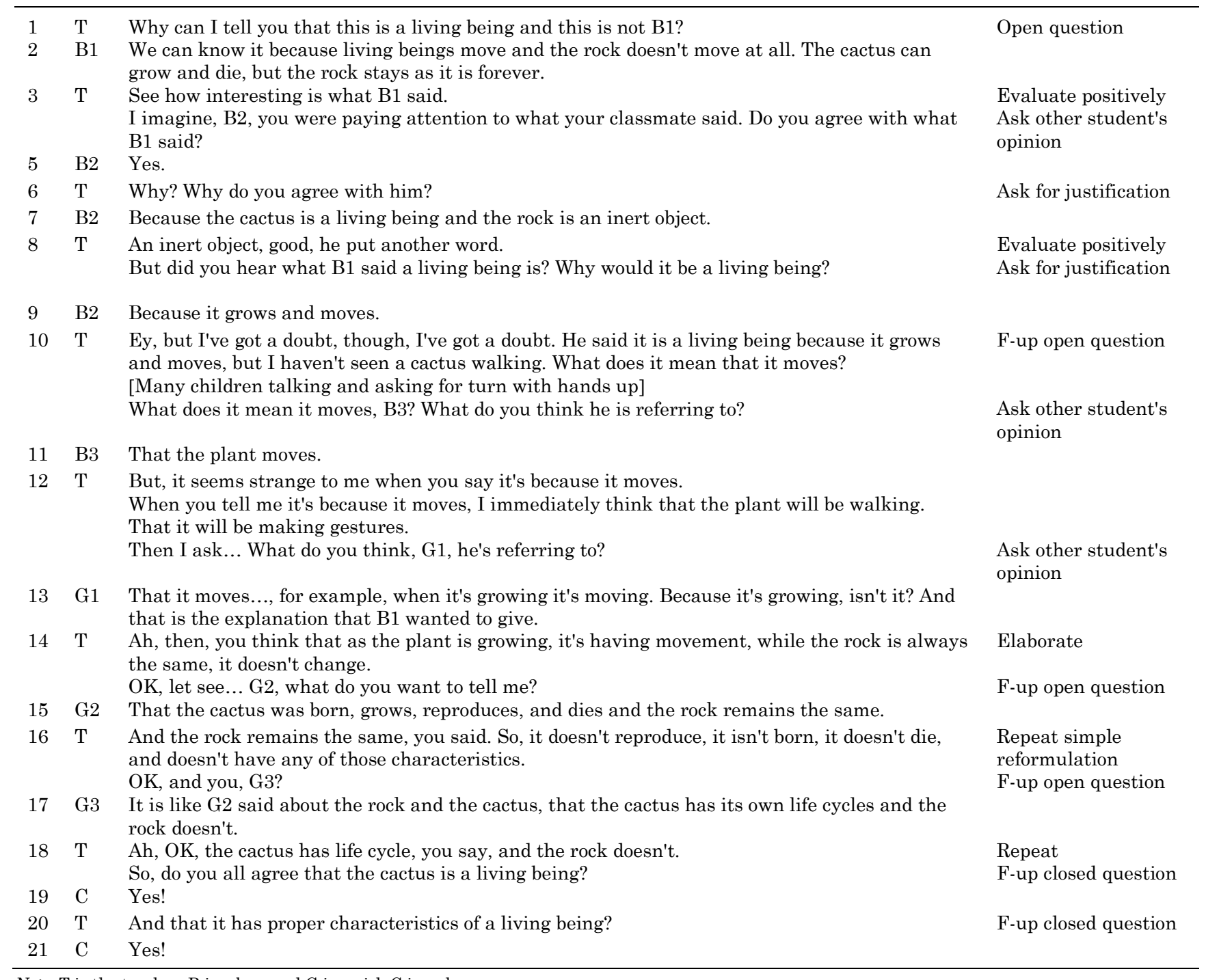

Note. $\mathrm{T}$ is the teacher; $\mathrm{B}$ is a boy, and $\mathrm{G}$ is a girl; $\mathrm{C}$ is a chorus.

Commentary. The discourse in this extract is dialogic/interactive, as different ideas were exposed and explored. Pupils showed great ability to express their thoughts using complex and extended language with a wide vocabulary. The average length of students' response was 12 words, and three responses even exceeded 20 words in length (turns 2, 13, and 17). The teacher started the sequence with an open question which invited contributions from different students to create a common definition of the difference between living and non-living beings. The sequence finished with a series of follow-up closed questions leading to a common consensus. In relation to the interpersonal dimension, there was broad participation. Six different students joined in the dialogue and in two cases (turns 2 and 15) they influenced how the classroom talk unfolded. The teacher demonstrated a specialized knowledge to orchestrate the interaction, cognitively challenged the students, asking them to justify their ideas and focus on what she had asked (turn 8) and requesting them to elaborate and think about their classmate's answer (turns 3, 10, and 12). Students responded readily to the teacher's demand, being able to justify and elaborate their classmate's contribution (turn 13) and reformulating what another student had said, even without being asked to do so, as in turn 17, where G3 reformulated G2's answer about the stages of the life cycle, which was the theme of the new topic. In this extract, it can be seen how the teacher was able to conduct a significant conversation, with the answers mainly being given by the students, who could express their knowledge about a specific topic in a precise and independent manner. In general, a high level of attunement between all the members of the classroom was 
evident in this classroom talk, with the teacher being aware of how to stimulate her students and they, in turn, were aware of how to participate in the dialogue.

\section{Discussion}

At the beginning of this work, it was noted that there is very little evidence concerning classroom talk in schools that serve communities from different socioeconomic backgrounds. Actually, the study of Harris and Williams (2012) is the only investigation which addresses the topic of classroom talk in schools serving communities from different SES directly.

The results of the present research conducted in two Chilean classrooms share some similarities with the findings of Harris and Williams's study conducted in 102 British classrooms. The most significant is the evidence encountered in both investigations that in more affluent schools, teachers use a greater proportion of open questions, while in schools serving children of lower SES, teachers use more closed questions. Whereas for the authors of the British study this evidence is synonymous with poorer quality of classroom talk and an indicator of teachers' low expectations, this study shows evidence how through the use of closed questions the teacher in the more vulnerable school was able to lead productive interactions in the classroom. In this study it is evidenced that by means of closed questions the teacher in the vulnerable school helped her students to move their understanding forward through a type of interaction that cannot be defined as poorer in quality but as a verbal interaction that was attuned to the contextual learning possibilities, thus constituting productive interaction.

The evidence that teachers from schools serving communities of lower SES employed a greater proportion of closed questions may be associated with the notion of strong framing developed by Bernstein (2000) to characterise pedagogic relations in which the teacher is in greater control of the interaction. The extended use of closed questions can indicate the need for children from disadvantaged areas to be more carefully guided in the learning interactions to consolidate their academic knowledge. This idea is supported by Cazden (2001), who reports that students from poorer areas could achieve the same results in a descriptive task as children from more affluent backgrounds; they only need more prompts from the adult to do so. Along the same lines, Castillo Gallardo (2014) describes interactions between mothers and children of lower SES in Chile as more adult dependent, as well as more concrete. Following these studies and the findings of the present research, it can be said that children of lower SES benefit from interactions in which the adult makes a greater effort to connect with the children's understanding and is able to guide their learning in a more thoughtful manner.

This study also found that students from lower socioeconomic backgrounds tended to express utterances that were less complex, shorter and more concrete, directly related to their personal experiences. These findings fit with Bernstein's (1970) definitions of restricted code as the language used in working-class interactions. Furthermore, the results of this study also correspond to the findings of Spencer et al. (2012), showing that students from disadvantaged areas employ less complex vocabulary and express shorter utterances.

The notion that lacking complex language constitutes a linguistic deficit is surely controversial, but less questionable when considering the empirical verification of its implications for academic achievement. It is necessary that research on different uses of language regarding contrasting socioeconomic backgrounds recognise the specific characteristics that shape the communicative experiences in a deeper sense in distinct social contexts that relate to different ways of making sense of teaching and learning experiences. It seems pertinent here to remember what Bernstein (1970) stated years ago, that "education cannot compensate for society" (p.61) and that schools should incorporate into their codes the one of their students to be able to respond accordantly and to make real communication possible. In so doing, schools would be enabling learning and at the same time recognising students' knowledge as meaningful and themselves as valid interlocutors.

If learning should start from children's previous knowledge, then the communicative interaction in which this learning is framed should also take their communicative knowledge into consideration. This is only possible if teachers are firstly able to understand and situate themselves within their learners' knowledge, perspectives, and usage of language. And just from that position teachers would be able to guide their students towards meaningful learning that considers, but at the same time goes beyond, cognitive development and academic achievement, thus also impacting the students' personal and social identities. 
This investigation has the limitation of using a small sample of only two $4^{\text {th }}$ grade classes studying science in Chilean schools that were purposely selected for their pedagogic commitment to dialogue. In this sense, the sample does not allow transferring the results to other settings that do not share the same characteristics (Denscombe, 2014). Since the schools in the study were chosen for their commitment to dialogue and participation, they do not represent the interactions that might be observed in other schools where participation is not promoted.

Regarding the implications for educational practice, the present study suggests that teachers working with children from economically disadvantaged groups in society should be aware of the use their students make of language to be able to promote real communication and academically productive interactions. Teachers in their everyday practice have a great opportunity to promote learning that is attuned to students' characteristics and needs. As school knowledge and academic language can be far removed from the linguistic experience of children of lower SES, the teacher's role becomes even more significant in these contexts. The results of this research suggest that students from disadvantaged areas would benefit from a type of verbal interaction that is actively and thoughtfully guided by the teacher, who needs to be constantly checking if the type of language being used in academic interactions is suitable for their students.

Future research on the topic of classroom talk variation that depends on SES should be conducted with larger samples, considering children of various ages and in other curriculum subjects. This would allow comprehension of the specific variations that depend on socioeconomic factors beyond pedagogic style, age, or academic content. It would be interesting to do investigations within the school and family contexts to observe the linguistic experiences of children from different backgrounds in both settings. Longitudinal studies including children from a young age would be highly illuminating to understand how children develop language and knowledge, both in their family and school contexts. Especially interesting would be to see the relationships, synchronies, and mismatches between both spheres of children's experiences.

\section{Conclusion}

Social inequality in terms of academic performance is a main concern for educational research and policymaking. Nonetheless, classroom talk is not considered when addressing this relevant social problem. Without recognising the actual differences in the use of language by children of different SES, classroom talk research will only contribute to broadening the gap between affluent and disadvantaged groups, rather than tackling social inequality.

The current study has highlighted the importance of teachers understanding and situating themselves within the linguistic knowledge of students from vulnerable groups of societies. From this position, teachers can encourage meaningful dialogue with their students, allowing academic learning to take place and also social recognition to develop. It is from this attuned position with their pupils that teachers will be able to move learning forward and use classroom talk as a malleable tool to overcome inequalities.

Even though it is necessary to carry out research with a larger sample, the findings from the current study, along with evidence on language variation according to SES, show that classroom verbal interactions with students of lower SES tend to be more adult-dependent and concrete. For this reason, it is suggested that pupils from disadvantaged groups of society would benefit from classroom talk that is consciously conducted in acknowledgment of those specific needs. Only from this attuned communication teachers would be able to expand the children's verbal repertoire. This has important implications for professional training and practice of teachers working in vulnerable schools, as their role becomes even more crucial in these educational contexts.

\section{References}

Abd-Kadir, J. \& Hardman, F. (2007). The discourse of whole class teaching: A comparative study of Kenyan and Nigerian primary English lessons. Language and Education, 21, 1-15. https://doi.org/10.2167/le684.0

Alexander, R. J. (2000). Culture \& pedagogy: International comparisons in primary education. Oxford, United Kingdom: Blackwell.

Bellei, C. (2013). El estudio de la segregación económica y académica de la educación chilena. Estudios Pedagógicos, 39(1), 325-345. https://doi.org/10.4067/S0718-07052013000100019

Bernstein, B. (1971). Education cannot compensate for society. In B. Cosin, I. Dale, G. Esland \& D. Swift (Eds.) School and Society. A sociological reader (pp. 61-66). London, United Kingdom: Routledge \& Kegan Paul in association with The Open University Press.

Bernstein, B. (2000). Pedagogy, symbolic control and identity: Theory, research, critique (revised ed.). Lanham, MD: Rowman \& Littlefield.

Castillo Gallardo, P. E. (2014). Juego ampliado, juego restringido: producciones simbólicas tempranas en contextos de desigualdad. Universitas Psychologica, 13(4), 15-26. https://doi.org/10.11144/Javeriana.UPSY13-4.jajr 
Cazden, C. B. (2001). Classroom discourse: The language of teaching and learning (2 ${ }^{\text {nd }}$ ed). Portsmouth, NH: Heinemann.

Cheshire, J. (2005). Syntactic variation and beyond: Gender and social class variation in the use of discourse-new markers. Journal of Sociolinguistics, 9, 479-508. https://doi.org/10.1111/j.1360-6441.2005.00303.x

Denscombe, M. (2014). The good research guide: For small-scale social research projects (5 ${ }^{\text {th }}$ ed.). Maidenhead, United Kingdom: Open University Press.

Edwards, D. \& Mercer, N. (1987). Common knowledge: The development of understanding in the classroom. London, United Kingdom: Methuen.

Hardman, F., Smith, F., \& Wall, K. (2003). 'Interactive whole class teaching' in the national literacy strategy. Cambridge Journal of Education, 33, 197-215. https://doi.org/10.1080/03057640302043

Harris, D. \& Williams, J. (2012). The association of classroom interactions, year group and social class. British Educational Research Journal, 38, 373-397. https://doi.org/10.1080/01411926.2010.548547

Hasan, R. (2002). Ways of meaning, ways of learning: Code as an explanatory concept. British Journal of Sociology of Education, 23, 537-548. https://doi.org/10.1080/0142569022000038396

Howe, C. \& Abedin, M. (2013). Classroom dialogue: A systematic review across four decades of research. Cambridge Journal of Education, 43, 325-356. https://doi.org/10.1080/0305764X.2013.786024

Jones, S. \& Tanner, H. (2002). Teachers' interpretations of effective whole-class interactive teaching in secondary mathematics classrooms. Educational Studies, 28, 265-274. https://doi.org/10.1080/0305569022000003717

Larraín, A., Howe, C., \& Cerda, J. (2014). Argumentation in whole-class teaching and science learning. Psykhe, 23(2),1-15. https://doi.org/10.7764/psykhe.23.2.712

Lefstein, A. (2010). More helpful as problem than solution. Some implications of situating dialogue in classrooms. In K. Littleton \& C. Howe (Eds.), Educational dialogues: Understanding and promoting productive interaction (pp. 170-191). Abingdon, United Kingdom: Routledge.

Littleton, K. \& Howe, C. (Eds.) (2010). Educational dialogues: Understanding and promoting productive interaction. Abingdon, United Kingdom: Routledge.

Mercer, N. (1995). The guided construction of knowledge: Talk amongst teachers and learners. Clevedon, United Kingdom: Multilingual Matters.

Mercer, N. (2004). Sociocultural discourse analysis: Analysing classroom talk as a social mode of thinking. Journal of Applied Linguistics, 1, 137-168. https://doi.org/10.1558/japl.v1.i2.137

Mercer, N. (2010). The analysis of classroom talk: Methods and methodologies. British Journal of Educational Psychology, 80, 1-14. https://doi.org/10.1348/000709909X479853

Mercer, N. \& Dawes, L. (2014). The study of talk between teachers and students, from the 1970s until the 2010s. Oxford Review of Education, 40, 430-445. https://doi.org/10.1080/03054985.2014.934087

Mizala, A. \& Torche, F. (2012). Bringing the schools back in: The stratification of educational achievement in the Chilean voucher system. International Journal of Educational Development, 32, 132-144. https://doi.org/10.1016/j.ijedudev.2010.09.004

Molinari, L., Mameli, C., \& Gnisci, A. (2013). A sequential analysis of classroom discourse in Italian primary schools: The many faces of the IRF pattern. British Journal of Educational Psychology, 83, 414-430. https://doi.org/10.1111/j.2044-8279.2012.02071.x

Mortimer, E. F. \& Scott, P. H. (2003). Meaning making in secondary science classrooms. Maidenhead, United Kingdom: Open University Press.

Myhill, D. (2006). Talk, talk, talk: Teaching and learning in whole class discourse. Research Papers in Education, 21, 19-41. https://doi.org/10.1080/02671520500445425

Nassaji, H. \& Wells, G. (2000). What's the use of 'triadic dialogue'? An investigation of teacher-student interaction. Applied Linguistics, 21, 376-406. https://doi.org/10.1093/applin/21.3.376

Organisation for Economic Co-operation and Development (2010). PISA 2009 results: Overcoming social background - Equity in learning opportunities and outcomes (Vol. II). Paris, France: OECD Publishing. http://hdl.voced.edu.au/10707/2498

Preiss, D. D. (2009). The Chilean instructional pattern for the teaching of language: A video-survey study based on a national program for the assessment of teaching. Learning and Individual Differences, 19, 1-11. https://doi.org/10.1016/j.lindif.2008.08.004

Preiss, D., Larraín, A., \& Valenzuela, S. (2011). Discurso y pensamiento en el aula matemática chilena. Psykhe, 20(2), 131-146. https://doi.org/10.4067/S0718-22282011000200011

Radovic, D. \& Preiss, D. (2010). Patrones de discurso observados en el aula de matemática de segundo ciclo básico en Chile. Psykhe, 19(2), 65-79. https://doi.org/10.4067/S0718-22282010000200007

Robson, C. (2011). Real world research: A resource for users of social research methods in applied settings (3rd ed.). Chichester, United Kingdom: Wiley.

Scott, P. H., Mortimer, E. F., \& Aguiar, O. G. (2006). The tension between authoritative and dialogic discourse: A fundamental characteristic of meaning making interactions in high school science lessons. Science Education, 90, 605-631. https://doi.org/10.1002/sce.20131

Sinclair, J. M. H. \& Coulthard, R. M. (1975). Towards an analysis of discourse: The English used by teachers and pupils. Oxford, United Kingdom: Oxford University Press.

Spencer, S., Clegg, J., \& Stackhouse, J. (2012). Language and disadvantage: A comparison of the language abilities of adolescents from two different socioeconomic areas. International Journal of Language \& Communication Disorders, 47, $274-284$. https://doi.org/10.1111/j.1460-6984.2011.00104.x

Wells, G. (1999). Dialogic inquiry: Towards a sociocultural practice and theory of education. Cambridge, United Kingdom: Cambridge University Press.

Wood, T. (1994). Patterns of interaction and the culture of mathematics classrooms. In S. Lerman (Ed.), Cultural perspectives on the mathematics classroom (pp. 149-168). Dordrecht, Netherlands: Kluwer Academic.

Fecha de recepción: Junio de 2018.

Fecha de aceptación: Marzo de 2020. 